\title{
Limestone millstones: Facies, provenance and use of sandy to pure limestones in France
}

\author{
Gilles Fronteau ${ }^{1}$, François Boyer ${ }^{2}$, Luc Jaccottey ${ }^{3}$, Vincent Le Quellec ${ }^{4}$, \\ Stéphanie Lepareux-Couturier ${ }^{5}$, Annabelle Milleville ${ }^{6}$, Cécile Monchablon ${ }^{7}$, \\ Boris Robin ${ }^{8}$, Paul Picavet ${ }^{9}$ \\ 1. Université de Reims Champagne-Ardenne, GEGENAA EA 3795, 51097 Reims, France. \\ Email: gilles.fronteau@univ-reims.fr \\ 2. Groupe-Meule, 65 rue Denfer Rochereau, F-92100 Boulogne-Billancourt, France. \\ Email: boyer.mill@gmail.com \\ 3. Inrap (Institut National de Recherches Archéologiques Préventives), UMR 6249, Laboratoire Chrono- \\ environnement, Besançon, France. Email: luc.jaccottey@inrap.fr \\ 4. Pôle archéologique du département de l’Aisne, rue Paul Doumer, F-02013 Laon cedex, France. \\ Email: vlequellec@aisne.fr \\ 5. Inrap (Institut National de Recherches Archéologiques Préventives), UMR 8546 CNRS ENS-Paris, France; \\ Archéologie et Philologie d'Orient et d'Occident (AOROC). École Normale Supérieure, 45, rue d'Ulm, 75005 \\ Paris, France. Email: stephanie.lepareux-couturier@inrap.fr \\ 6. Labex TransferS, Ecole normale superieure, 45 rue d'Ulm, 75230 Paris cedex 05, France. \\ Email : annabelle.milleville@ens.psl.eu \\ 7. Inrap (Institut National de Recherches Archéologiques Préventives), UMR 8215 "Trajectoires. De la \\ Sédentarisation à l'État", Centre archéologique Inrap, 32 rue Delizy, 93694 Pantin cedex, France. \\ Email: cecile.monchablon@inrap.fr \\ 8. Groupe-Meule, 8 rue de Verdun, F-45430 Checy, France. Email: boris_robin@yahoo.fr \\ 9. Université de Lille, CNRS, Ministère de la Culture et de la Communication, UMR 8164 - HALMA - Histoire \\ Archéologie Littérature des Mondes Anciens, F-59000 Lille, France. Email: paul.picavet@gmail.com
}

\begin{abstract}
:
Limestones are sedimentary rocks more commonly associated with building stones or sculptures than with millstones. Nevertheless, many examples of limestone saddle querns, rotary querns and millstones are spread across France, at times making up the bulk of the archaeological assemblages in various areas characterized by bedrocks rich of sedimentary stones. These limestone millstones are of different types, sources and geological origins: Eocene sandy or fossiliferous limestones, mainly from the various limestones layers from the Lutetian beds, Quaternary calcareous tufas, and fine Jurassic limestones. To explain the behaviour of these rocks, this study advances a classification of the rocks used for millstones, focused not only on the rock-type but mainly on the topological aspect of the stone surface. (empirical macroscopic surface roughness) This renders it possible to classify the rocks into categories by materials, rather than according to petrographic facies. The pure limestones in this study are essentially vacuolar, whereas sandy limestones or certain biodetritital limestones belong to either the granular rocks category, which also includes sandstones, or to the category of heterogeneous rocks. These limestones appear for the most part to have been used due to their availability. Moreover, they epitomise a very satisfactory compromise between their grinding properties and their ease of
\end{abstract}

Published by the School of History, Classics and Archaeology, University of Edinburgh ISSN: 2055-0472. URL: http://journals.ed.ac.uk/lithicstudies/

Except where otherwise noted, this work is licensed under a CC BY 4.0 licence. 
carving, even if the hardness of these limestones is lower than those of other rocks used as grindstone (basalts or sandstones).

Keywords: saddle quern; rotary quern; millstone; limestone; petrography; geomaterial

\section{Introduction}

Limestones are common construction geomaterials that served either in the form of rough stones or dimension stones (Degryse et al. 2003; Fronteau et al. 2010, Viscusi-Simonin \& Jaccottey 2013). Limestone also serves for sculpture and ornamental stone (Dalmau 2015; Harrell \& Storemyr 2009; Martínez-Torres 2009) and is the main raw material of lime production (Dix 1982; Karkanas 2007). Its use as a tool, although regularly recorded, is less frequent (Donnart 2015; Hamon et al. 2009; Larocca 2016; Milleville 2007; Peacock 1987; Spivak \& Nadel 2016).

Like many other sedimentary rocks, notably sandstones (Hamon 2006; Hamon \& Fronteau 2018; Reniere et al. 2016), limestones are endowed with a variety of lithological, petrographical and petrophysical characteristics even, at times, in the same geological formation, deposit or quarry (Picavet et al. 2018). These rocks can therefore serve to carry out certain functions or, in contrast, reveal characteristics that render them incompatible with an efficient use for a given function. Indeed, certain facies can either be very porous and not resistant like e.g., chalk or, on the contrary, microporous but frost-resistant, macroporous or massive (Fronteau et al. 1999). Limestones, serving as paving or as decorative elements, are thus sometimes used like marbles, rocks with which they share certain technical characteristics without possessing identical textural properties (Brilli et al. 2011; Ferrini et al. 2012).

\subsection{Definitions of limestone types}

The different common denominations of chalk, limestone, and marble correspond more to terminologies and technical classifications than to geological classifications. Chalks are very fine grained and white to grey-green limestones or marly limestones. Many marbles are compact limestones and not true geological marbles.

The term limestone, however, has a precise, albeit broad geological definition: it is defined as a carbonate sedimentary rock containing at least $50 \%$ of calcite $\left(\mathrm{CaCO}_{3}\right)$ (Tucker \& Wright 1990). Yet, this definition does not take into account textural criteria or conditions of how it was formed. Limestones can be of marine or continental origin and petrographically very different: granular or rich in matrix, fine or coarse, porous or massive, friable or very compact (Flügel 2010; Reedy 2008).

From a strictly mineralogical point of view, there are large varieties of sedimentary rocks such as detrital rocks (siliciclastic or bioclastic), clay-carbonate rocks and dolomitic rocks (Figure 1). Limestones represent an end member of the vast array of sedimentary rocks. Yet a limestone can be partially sandy, clayey or dolomitic. Each of these series has one or more classifications which are defined by their ranges of composition qualified by percentages of minerals or chemical elements.

The mineralogical proportions of sedimentary rocks can at times vary considerably within the same quarry. It is not uncommon for a sequence in a quarry to vary from a sand to a sandy limestone and then to a real limestone in the space of a few meters. This sometimes puzzles certain archaeologists who doubt whether to classify their tools as sandy limestone or sandstone with a calcareous matrix and must rely on reference documents to classify the panoply of facies contained in their assemblages (Anderson et al. 2003; Fronteau et al. 2017) 
Different classifications have been developed to overcome the lack of precision of the term "limestone" with respect to the capacities of its use. The objective of these classifications was to characterise limestones from a petrographic point of view and, in particular, to take into account its potential as a reservoir rock. The two most widely used classifications to characterise limestones are the work of Folk (1959) and Dunham (1962). They are quoted in most geological publications and serve as references in the international standards for the characterisation of natural stones (European standard 2007). Folk's classification, based essentially on petrographic criteria obtained by optical microscopy, defines limestones according to the nature of their elements (ooids, bioclasts, oncolites, pelletoids) and their binder (sparite, micrite). Dunham's classification, in turn, focuses more on the texture of the material (grain-supported, matrix-supported) and the proportion of elements (mudstone, wackestone, packstone, grainstone). Dunham's classification was completed by Embry \& Klovan (1971), who added biogenic textural classes (bindstone, boundstone, framestone), and revised by Wright (1992), who especially added some terms for diagenetically highly modified limestones (cementstone, condensed grainstone, fitted grainstone).

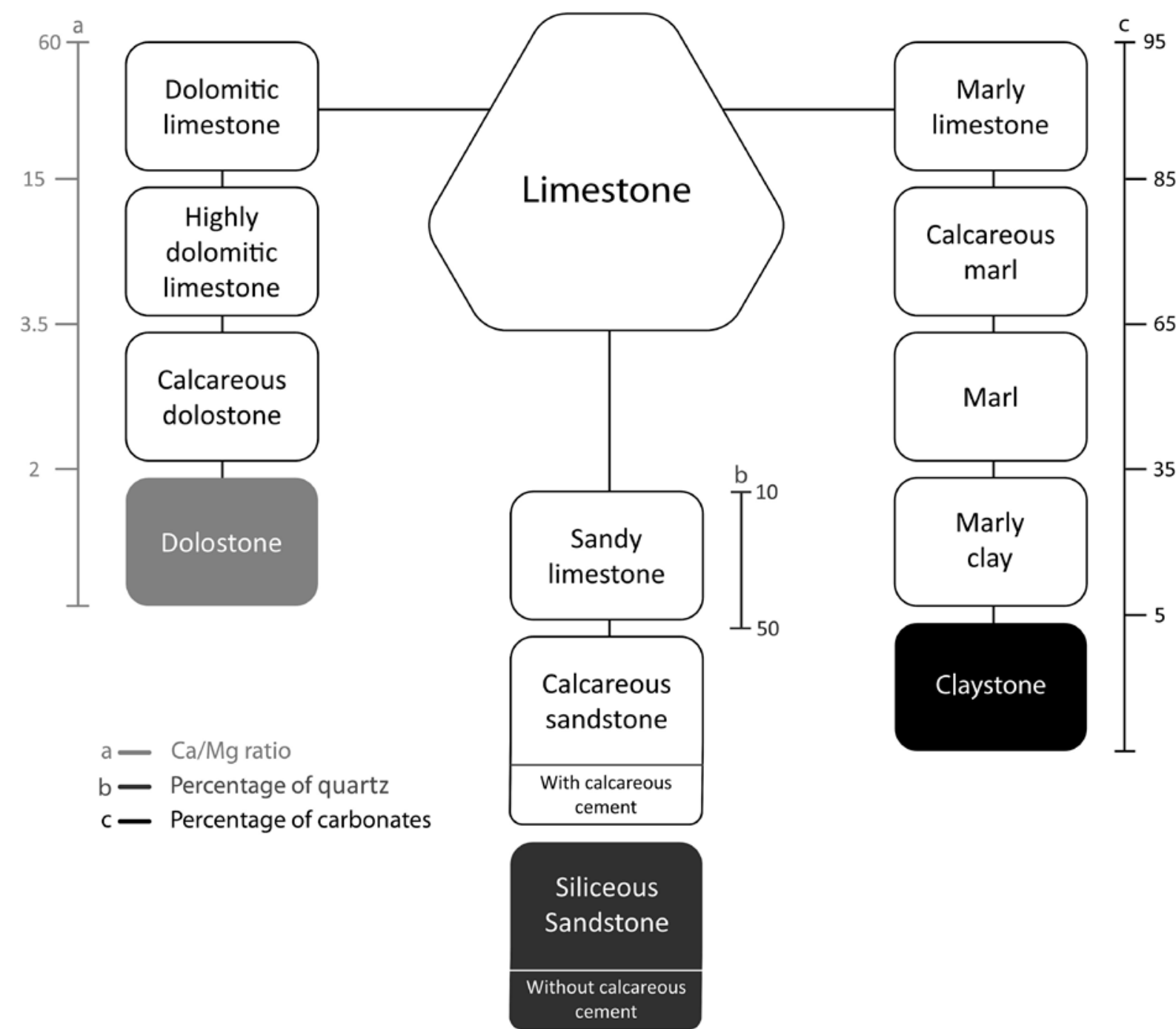

Figure 1. Classification of sedimentary rocks including limestones as an end member of the sedimentary series.

The two classifications serve for pure limestones and refer to rocks from marine contexts (Scholle \& Ulme-Scholle 2003). Yet, they are poorly applicable to characterise sandy limestones or continental limestone rocks (calcrete, lacustrine limestones). Furthermore, they 
do not really consider the notions of porosity (as detailed by Choquette \& Pray 1970), cohesion or resistance. Hence, the Folk and Duham classifications (often used together), are currently supplemented by petrophysical analyses or by additional older or younger terminologies, as e.g., calcilutite, calcarenite, calcirudite (Grabau 1904), referring to limestones sorted by granulometry.

Although physicochemical and petrophysical analyses are important to compare the different materials, they do not lead to a simple classification of the materials (Delgado-Raack et al. 2009). Differences in terms of the type of limestone materials are noted, particularly in the field of building stones (Noël 2012): strong, half-strong, soft, firm, half-firm. $19^{\text {th }}$-century specialists devised a system of classification by dividing the limestones into groups according to technical characteristics, their potential use and their durability (Michelot 1863). But these criteria were not precise and certain terms differed according to type of use, region and trade names. This default led to the gradual abandonment of these classifications in favour of other more quantitative and reproducible criteria. The classifications of the 19th century still maintained the advantage of a concrete connection between the type of limestone and its technical characteristics of resistance, shaping or durability. They also had the merit of recognising and identifying several types of limestone within the same geological formation, or in the same quarry. For example, among the Lutetian limestones in the area of Paris, the terms "vergelés" (very soft limestone shell mould), "liais" (a fine, massive and very hard limestone without shells) or "banc francs" (easily carved shell-rich limestones) reflected material properties and initially were not simply commercial names (Benoît et al. 2000).

\subsection{Definitions of types of materials serving for millstones and their application to limestones}

Recent research in France and Belgium within the framework of the "Groupe Meule" has sought to define millstone material types according to the pragmatic classification of Fronteau \& Boyer (2011). These types serve as a supplement to the rock's normal standard nomenclature (European standard 2003; 2008) and its petrographic (European standard 2007), petrophysical and geochemical characterisations. This enables a comparison of the behaviour of millstones made of different lithological groups (volcanic, sedimentary, metamorphic) or offers guidance in the characterization of differences between categories of millstones within the same lithology or facies (Hamon 2006). Thus, this definition corresponds to the recent classification of millstone quarries by Anderson (2016), which rather focusses on the type of site and the means of extraction, independently of the rock type.

In the classification advanced in the paper (Figure 2), which is usable not only for limestones but for all rock types, certain categories are strongly related to one rock family while others can be found among all rock types.

Category A corresponds to granular materials where the grains - here in the sense of a mineral or rock grain (lithoclast) that is more or less worn and rounded - are almost all of the same mineralogy, with quartz in the case of sandstones and calcite in the case of calcarenites. These rocks are rather coarse $(0.5 \mathrm{~mm}$ grains and larger), with a roughness linked to the texture between the grains and not to differences in mineral hardness (Schoumacker 1993). The classification differentiates category A1, comprising materials with a low level of cohesion between grains, which is common in the case of loosely cemented sandstone, and category A2 with a well-cemented facies, showing a strong granular cohesion (Hamon \& Fronteau 2018).

Category B corresponds to heterogeneous materials containing only a few coarse hardminerals embedded in a cement or matrix. The roughness depends on the frequency of the 
abrasive inclusions. Sandstones cemented with calcite, sandy limestones and rhyolites fall into this category.

Category C corresponds to materials with crystalline rugosity where the rock is entirely composed of hard minerals, or of an alternation of crystals of different hardness, as in the case of granites. Their roughness is often quite low and related to differences in hardness or in orientation between the minerals.
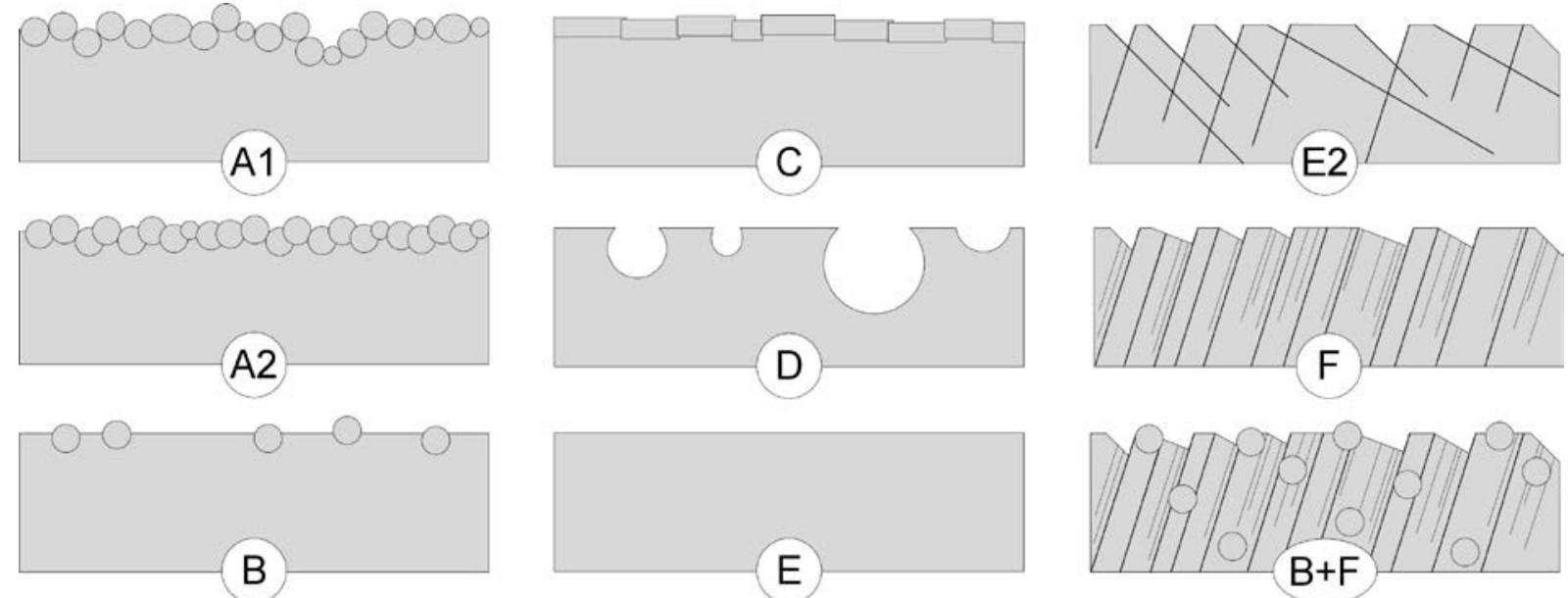

Figure 2. Classification of millstone rocks according to Fronteau \& Boyer 2011 (modified). A1: granular materials with low cohesion, A2: granular materials with high cohesion, B: heterogeneous material with few abrasive grains in a "soft" matrix, C: crystalline materials (grained), D: vacuolar materials, E: massive materials, E2: massive materials with fracture network, F: foliated or heavily laminated materials, B+F: example of a material with composite properties (foliated and heterogenous).

Category D groups all highly vacuolar materials such as varieties of basalts, siliceous rocks and limestones. The term "vacuolar" describes large macropores which can create a network of depressions on the active surface of the tool.

Category E materials can also belong to all rock families. These are clearly massive and generally result in poor grinding tools because of their lack of roughness. They are, by contrast, well adapted to other functions or can serve for grinding after being dressed with pecks or furrows (Lepareux-Couturier 2014). If the material has a network of fractures or natural micro-fissures, its massiveness can be modified so that it offers a potentially effective "bite" (category E2).

Finally, category F corresponds to schists, mica schists and very finely laminated sedimentary rocks. The heterogeneities between the laminations or foliations provide the coarseness for the abrasion.

Mixed behaviours can be observed in certain cases, as e.g., garnet porphyroblast mica schists (Prøsch-Danielsen \& Heldal 2014) which bear properties of both categories B and F.

\section{Limestone millstones from France}

\subsection{Sandy limestone querns}

Limestones serving to manufacture millstones vary both in the petrographic and the technical sense. These limestones or partially carbonated rocks can be differentiated into two groups: true or "pure" limestones and "impure" limestones. Sandy limestones or calcareous sandstones are well-known examples for millstone raw materials (Anderson et al. 2003; Robert \& Landreat 2005). Their use is easy to interpret because they correspond to rock types that resemble sandstones and make up the majority of the millstone rocks in sedimentary substrata. The abrasiveness of sandy limestones is ensured by the grains of quartz or other 
hard minerals bound more or less effectively in a calcareous matrix. In certain bioclastic limestone querns of the assemblages of the Burgundian Middle Neolithic (first half of the 4th millennium BCE) at Montmorot (Jura) and Bourguignon-les-Morey (Haute-Saône), shell fragments play the same role. This is also the case with well-crystallised limestones with angular grains of calcite within a finer interstitial material (Milleville \& Jaccottey 2015). These materials correspond to category B of the classification. Moreover, certain very sandy facies, at the limit of being calcareous sandstones, can also be interpreted as type A2.

Furthermore, since limestone elements can be partially dissolved, these materials often include a vesicularity that will probably not be found in analogous sandstones. In the reality of natural deposits, these limestone and siliciclastic mixed rocks are often present in form of a wide range of facies in the same sedimentary deposit, or even the same quarry. One example can be observed in the Lutetian layers of the Paris Basin (Figure 3a) where the facies varies vertically from a weakly cemented calcareous glauconitic sand to a less sandy and more massive limestone. This sedimentary formation was exploited for the production of Neolithic and Protohistoric saddle querns (Monchablon, in press), as well as for rotary querns (Audebert \& Le Quellec 2014; Jodry et al. 2017; Picavet et al. 2011; Pommepuy 1999; Robert \& Landreat 2005), corresponding to changes in the sedimentological context: the limestone banks proceed from categories A1 to A2 (Figure 3a), then to B, before become E type (or E + D), which then served mainly as a building stone (Devos et al. 2010; Fronteau et al. 2010). The calcareous upper layers, where the quartz grains make up less than $10 \%$ of the rock, again provided material suitable for millstones: an annelid-rich facies (Ditrupa strangulata limestone; Figure 3b) and a coarse shelly limestone (Figure 4).

\subsection{Pure limestone querns}

The other limestones widely serving for the manufacture of millstones in the centre of the Paris Basin are from the Upper Lutetian (Eocene) formations, notably cerithids limestones and Lymnaea limestones (Buchsenschutz et al. 2017; Fronteau et al. 2017; Pommepuy 1999). These limestones are almost completely devoid of quartz grains but rich in microfossils (miliolids) and imprints of dissolved gastropod shells (cerithids) (Figure 5). They are vacuolar, sometimes with a massive tendency (D, D + E or E + D). In eastern France, shelllike limestone querns, also vacuolar, are present in the Burgundian Middle Neolithic layers at the settlement of Clairvaux VII or at the Montmorot enclosure in the Jura (Milleville \& Jaccottey 2015).

In addition to these Eocene marine limestones, the north of France includes examples of Holocene (Quaternary) vacuolar lacustrine limestone querns, where the components are bound by a matrix of microcrystalline calcite (micrite) or by secondary cements of macrocrystalline calcite (sparite) (Figure 6). These pure limestones do not contain any hard-mineral elements and their abrasiveness is solely linked to the presence of vacuoles, or to the difference in crystallinity between the micrite and sparite elements which do not share the same mechanical behaviour, although composed of the same mineral (calcite).

The last example of a pure limestone millstone is a rotary quern brought to light in southeastern France at Jacob-Bellecombette (Savoie) (Figure 7). This calpionellid limestone, typical of Upper Jurassic-Lower Cretaceous layers, is totally devoid of quartz grains and has very fine facies, practically devoid of macro-pores or inclusions (Figure 7b), with the exception of a few microfossils (Calpionella alpina): it is a micrite to biomicrite according to Folk, and mudstone to wackestone in the sense of Dunham. This massive category E rock initially appears totally unsuitable for millstones. But as it can be seen in Figure 7a, its outcrops are significantly affected by fracturing and micro-cracking which leads to a certain roughness of the material. Therefore, the roughness is not related to the micro-facies or 
texture of the rock, but to its cracked structure. This leads to its classification as a subtype of the category E (E2 fractured massive material).
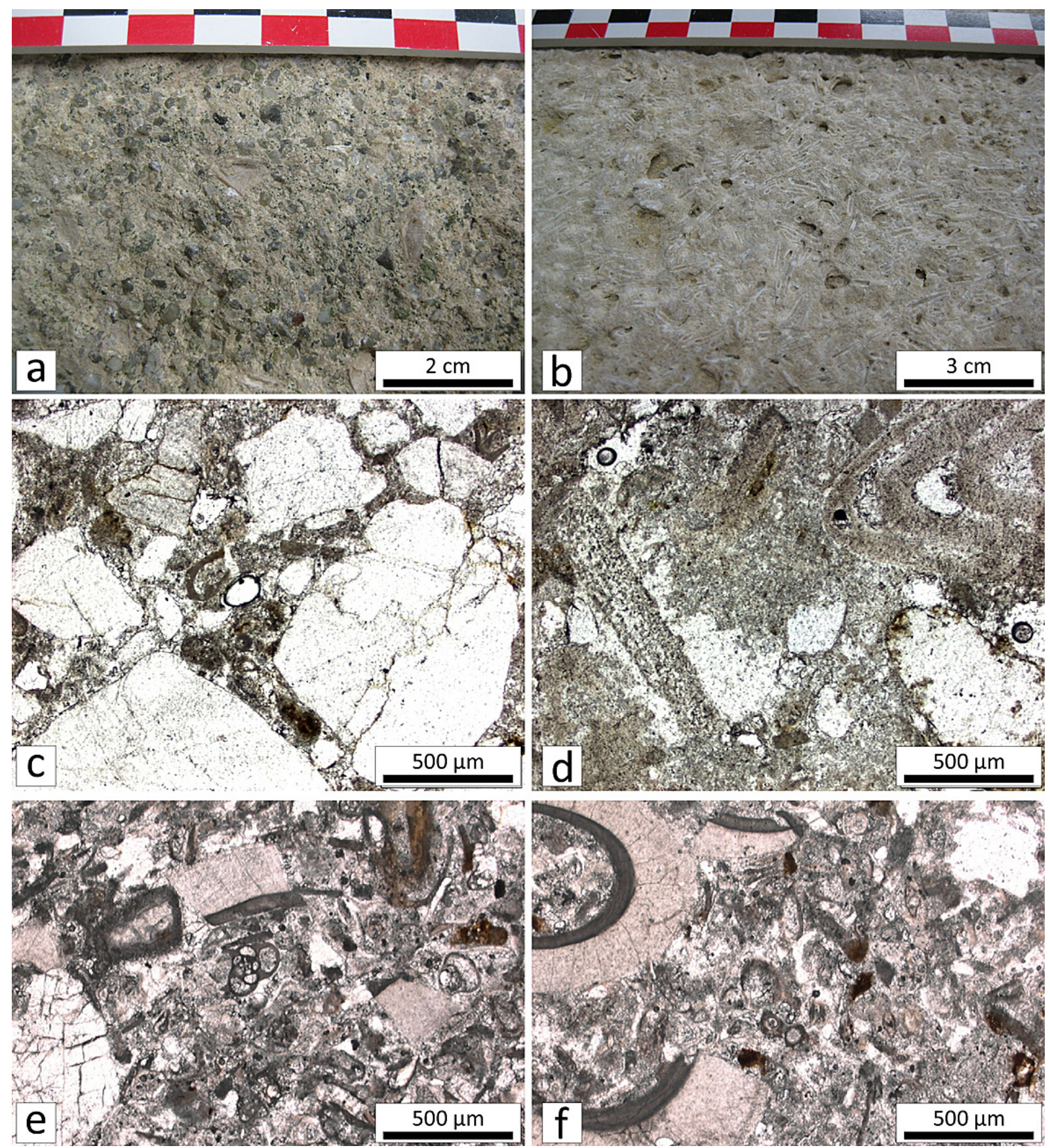

Figure 3. Rotary millstones in limestones from the center of the Paris Basin (France). 3a: macrophotography of a sandy limestone with glauconitic grins and few Nummulites laevigatus, 3b: macrophotography of a pure limestone with numerous Ditrupa strangulata, 3c and 3d: microphotography of a sandy limestone with Nummulites laevigatus, $3 \mathrm{e}$ and 3f: microphotography of a limestone with Ditrupa strangulata. (microphotography under planed polarised light). 


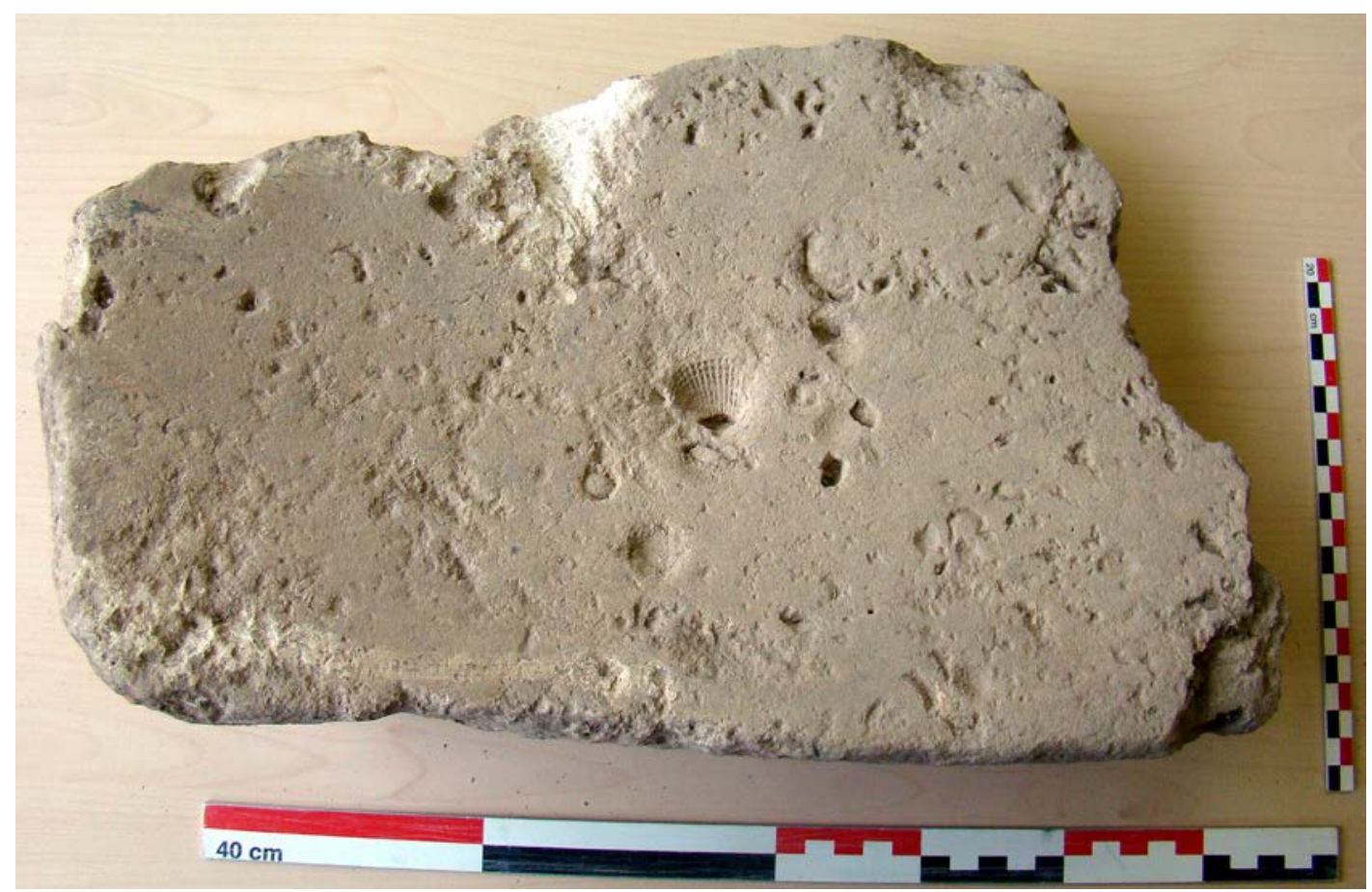

Figure 4. Example of a very slightly sandy vacuolar limestone saddle quern with a grinding surface tending to become massive. Early Iron Age (Hallstatt), Reims area, France.
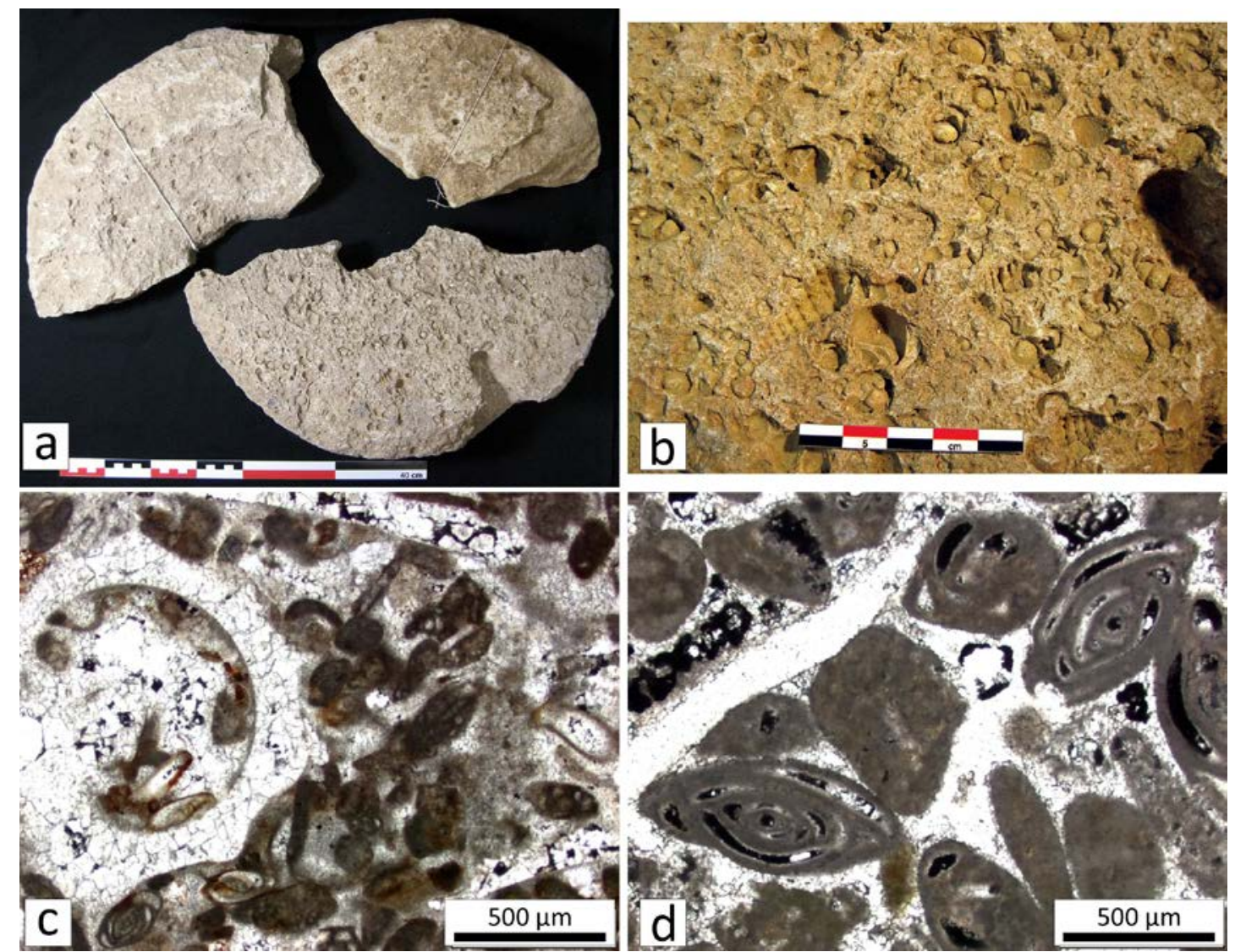

Figure 5. Example of a cerithids limestone rotary quern (diameter: $47 \mathrm{~cm}$; thickness: $7.9 \mathrm{~cm}$ ) catillus with an oval shaped eye (max. $13 \mathrm{~cm}$ ) recovered in a pit (F.8014, sector H) among about 30 other quern fragments corresponding to at least five different individuals. The pit, dating from the Late Iron Age (La Tène finale 2b), was excavated in 2009 at Barenton-Bugny, Hauts-de-France, France. 5a and 5b: macrophotography, 5c and 5d: microphotography under planed polarised light. 

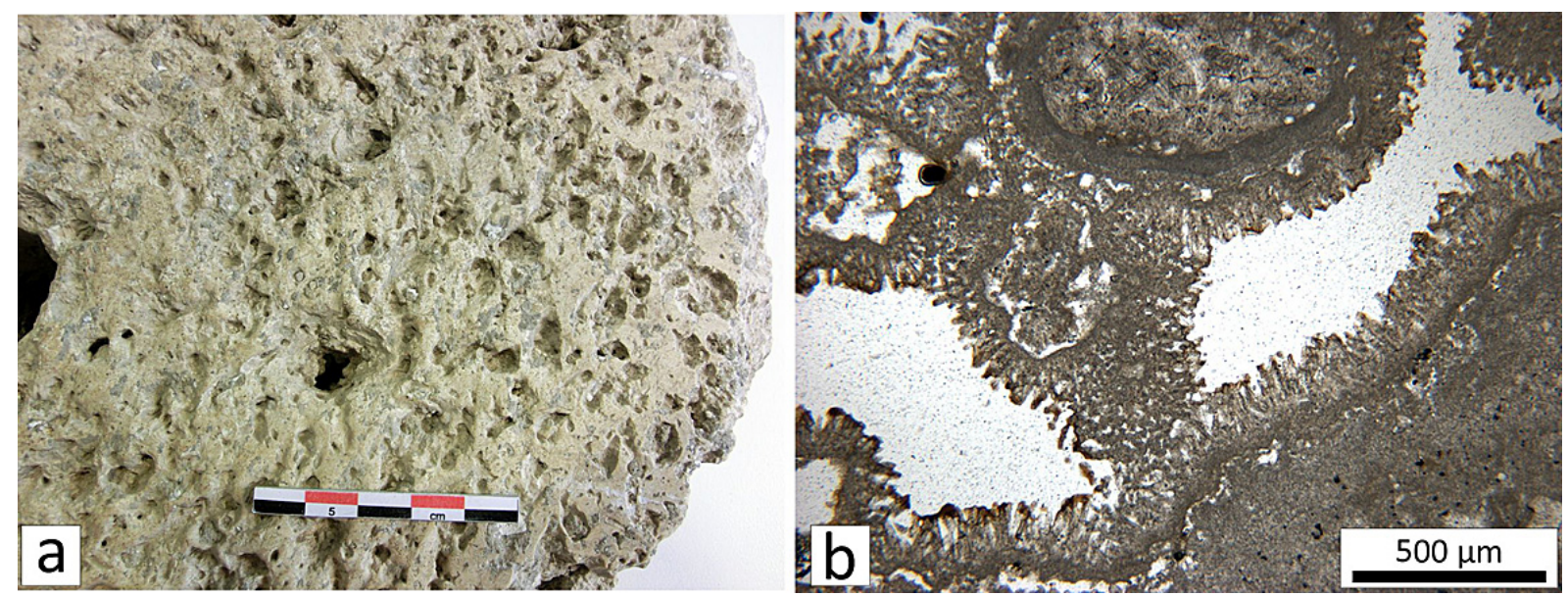

Figure 6. Lacustrine calcareous tufa rotary querns. These are the earliest rotary querns in the Nord-Pas-de-Calais in France. 6a: macrophotography, 6b: microphotography under planed polarised light.
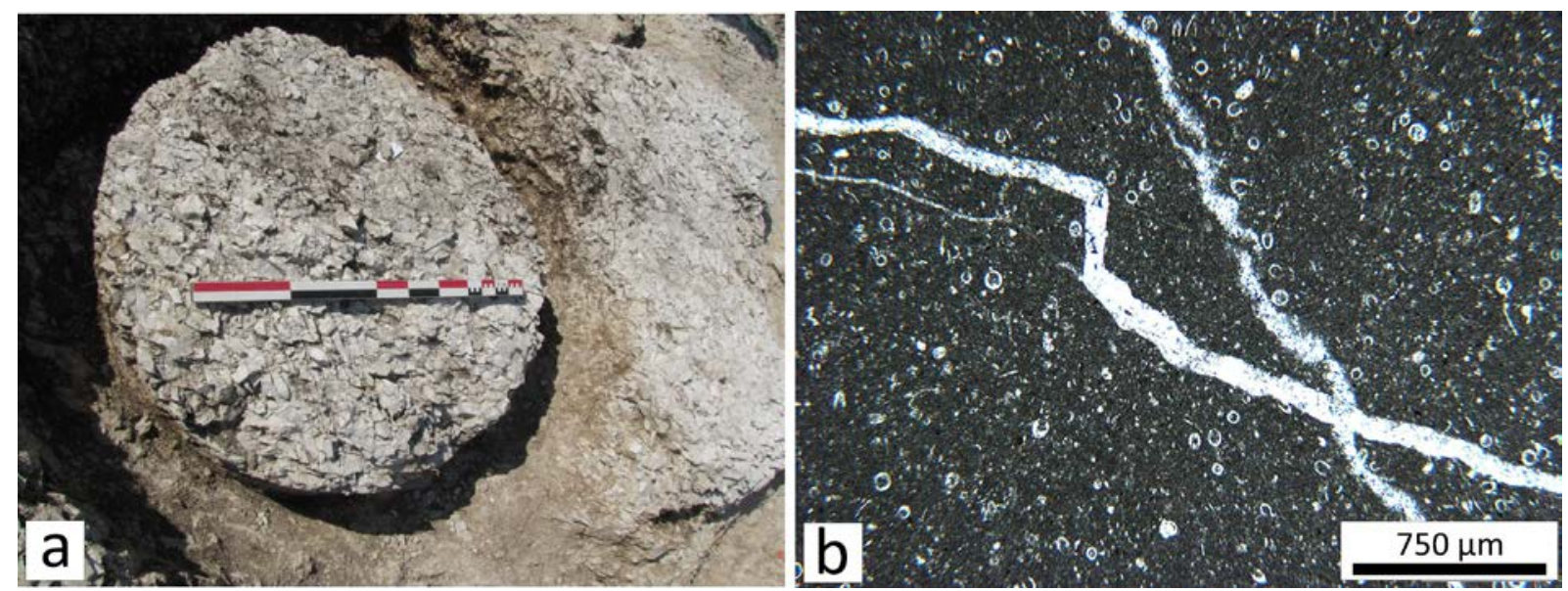

Figure 7. Modern millstone roughout of fine fractured limestone unearthed at the Jacob Bellecombette quarry (Savoie, France) (photo: Simon Painsonneau, Arkemine).

\section{Discussion}

Using sandy limestones to manufacture saddle or rotary querns is easy to understand because these stones can bear strong resemblances in their material properties to sandstones. Sandy limestones are therefore either materials with granular elements of type A2 or heterogeneous materials with occasional hard inclusions (type B). Yet, as noted above, millstones hewn of pure limestone (devoid of quartz grains) also form part of certain assemblages. The abrasiveness, crucial to milling with these limestones, is achieved essentially by their vacuoles, which are often the result of the dissolution of fossils (type D). Other limestones tend to behave as massive materials due to their lack of quartz grains (types $E+B$ ) or due to a lesser number of vacuoles (types $E+D$ ). The millstones of JacobBellecombette (Savoie), for example, led to defining type E2 for massive materials as their abrasiveness is linked to micro-fissures that result in undulations and irregularities over the millstone's active surface. Finally, there is the case of Holocene lacustrine limestones composed of soft microcrystalline calcite and more resistant macro-crystalline calcite cementations: these limestone materials, comprising both micrite elements and sparite crystals, act like a granular crystalline material (type C). Yet vacuolar grinding surfaces are clearly predominant (type D) among all the calcareous tufas examined in this study.

To explain the use of limestone for millstones, the first step is to examine if the choice of pure, vacuolar or massive limestone was intentional or if it was opportunistic. For example, 
the material may have been used merely due to its presence at the same outcrop of sandy limestones (or sandstone) or of pure limestone.

This question is indeed relevant in the case of the Lower Lutetian limestones (see Figure 3) which directly sit on top of calcareous sandstones. The detailed study of the Lutetian limestone quern assemblages around Reims, and the exhaustive characterisation of the rotary querns of the La Tène settlement of Acy-Romance (Buchsenschutz et al. 2017), indicate that Upper Lutetian shelly vacuolar limestones were deliberately extracted. Rotary querns made from this material in this assemblage (Figure 8) are clearly more numerous (number $=54$ ) than those carved from both the Middle Lutetian (number $=4$ ) and Lower Lutetian (number = 4) facies. This is corroborated by the series of querns from sites in the Aisne and Oise Valleys or the workshop area of the site of Griffon spanning the Late La Tène period until the $1^{\text {st }}$ century CE (Audebert \& Le Quellec 2014). In the local geological series, the Lower Lutetian with Nummulites and the Upper Lutetian cerithids or Lymnaea limestones are separated by around 15 metres in height. Furthermore, according to the geomorphological conditions in this area of the Paris Basin, it seems unlikely that these two facies can be found in the same quarry or outcrop. Thus, on the one hand, there probably existed quarries in which specifically pure limestone with gastropods imprints (Upper Lutetian) were exploited, and on the other hand quarries in which the lower sequences (nummulitic limestones from Lower Lutetian) were extracted.

Were limestone querns distributed exclusively locally? Limestone querns are at times considered simply as the result of opportunistic productions, a rather pejorative notion equivalent to an idea of non-choice. To appraise this view, the current study examined the spatial distribution of Lutetian limestone querns, a type that is easy to identify due to its macro and micro fossils (Fronteau et al. 2010; Robert \& Landreat 2005). The maps in Figure 9 depict both the distribution of Lutetian limestone rotary querns in the north of France and the extension of the sources of this limestone throughout the north of the Paris Basin. This rock, type 3 category of the Boyer \& Fronteau (2011) classification, occurs over a large area. Due to relatively homogeneous characteristics of the sedimentary layer, a precise provenancing is difficult. The main Late Iron Age sites (Figure 9a), including Acy-Romance that comprises the largest assemblage of rotary querns, are located in the Champagne Plain, about 35-40 km from the nearest outcrop. Other occurrences of these rotary querns are also observed in the plains of northern France, at a maximum distance of $100 \mathrm{~km}$ from the nearest outcrop. This distance increases to $130 \mathrm{~km}$, considering the sources of the Aisne Valley where two Gallic or Gallo-Roman quarries are identified (Vauxrezis: Robert \& Landreat 2005; Vendresse-Beaulne: Naze et al. 2011). The distribution of Lutetian limestone rotary querns in Roman times differs from that of the Late Iron Age (Figure 9b), but here again, the sites with the largest number of Lutetian limestone rotary querns are beyond the outcrop area of this rock. The average distances are comparable to those of the previous period, with several sites in the plains of northern France and Normandy that are located at about $100 \mathrm{~km}$ from the first Lutetian limestone outcrops and more than $150 \mathrm{~km}$ from those in the Aisne Valley.

The use of limestone to produce millstones is therefore not only linked to its availability or opportunism. Certain limestone millstones were exported far beyond the immediate surroundings of their natural outcrops, and distribution maps of different chronological periods reveal networks supplying these millstones to milling sites at long distances from their source. 


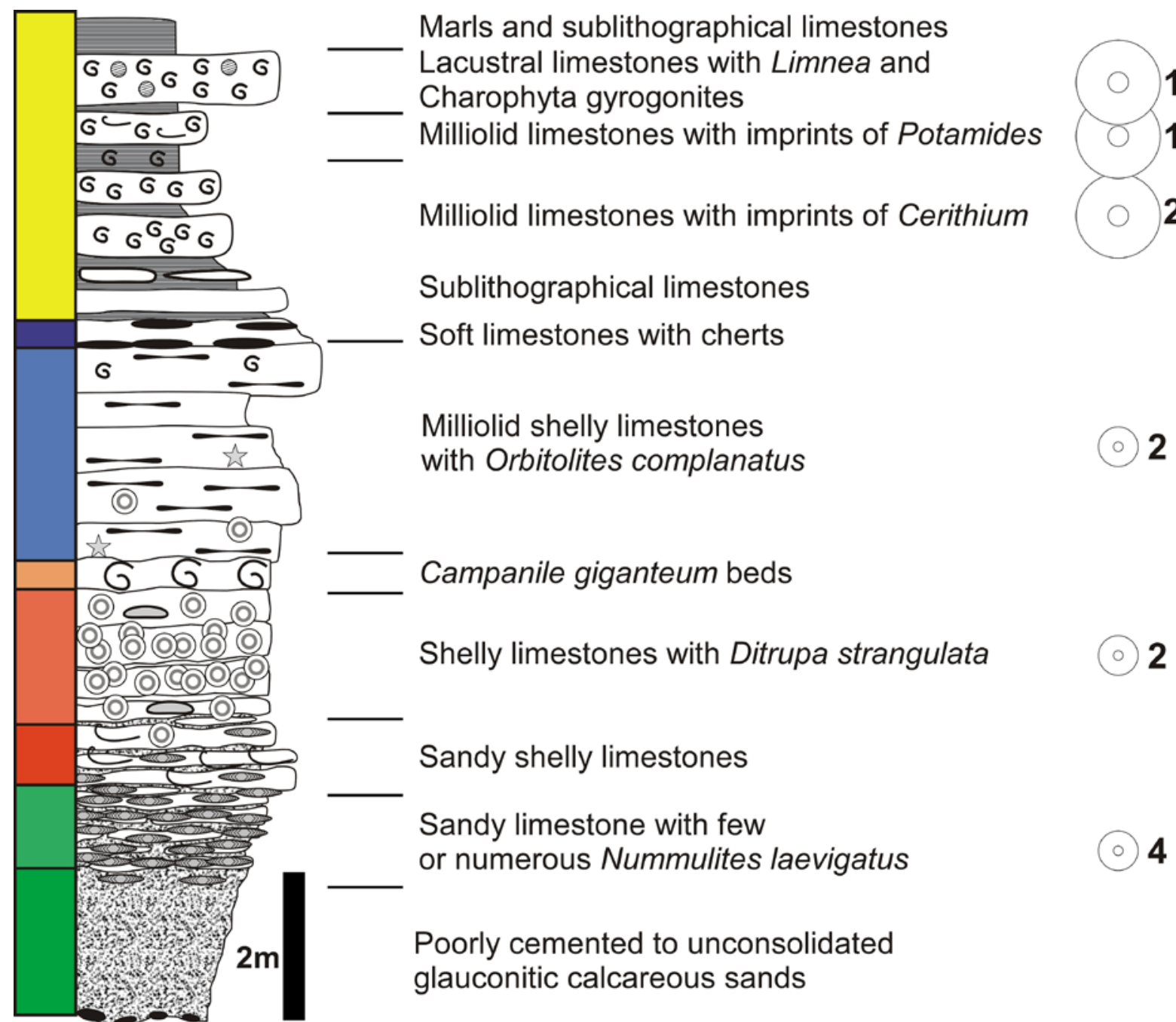

Figure 8. Columnar section of the Lutetian limestones layers from the area of Reims and, to the right, the respective quantities of rotary querns from the Late Iron Age (La Tène) settlement of Acy-Romance, Ardennes, France (Buchsenschutz et al. 2017).

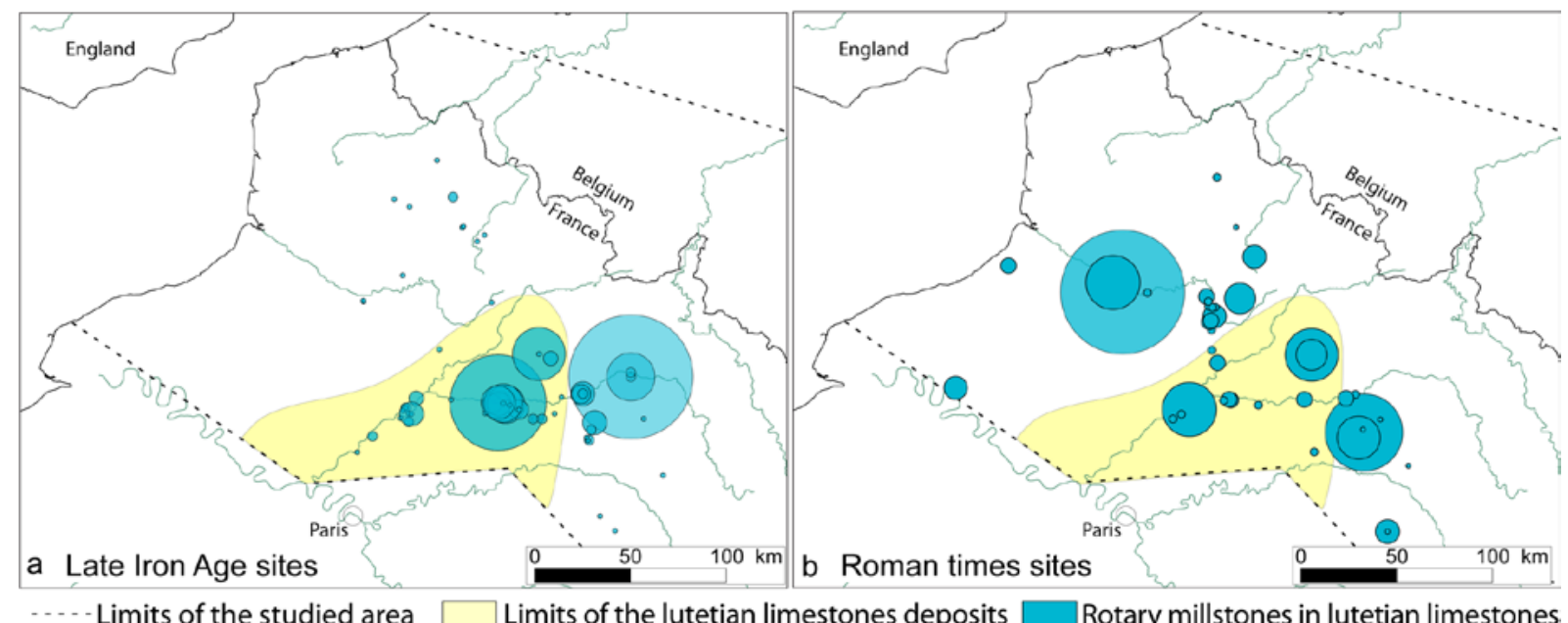

Figure 9. Lutetian limestone rotary querns from the north of France. Distribution of rotary querns beyond the extension of the limestone outcrops.

Moreover, the extent of the selection of this rock type varies significantly over a greater period of time in the same geographical area. In certain periods this raw material recurs on a 
large spatial scale, as testified for example by the use of limestone saddle querns (Pommepuy 1999), while limestone is totally absent at other periods. The example presented here (Figure 10, from Jaccottey \& Milleville 2017), corresponds to all the millstones studied in the regions between the Morvan and the Vosges in eastern France (Minimum Number of Individuals = 2148), spanning the beginning of the Middle Neolithic (around 4700 BCE) to the outset of the Late Iron Age (La Tene; around $400 \mathrm{BCE}$ ). In contrast to previous periods, limestone querns were exclusively used during the Middle Neolithic II (Burgundian Middle Neolithic) at the lake dwelling settlements of Clairvaux (Milleville 2007) and at certain fortified enclosures (e.g., Lavans-les-Doles, Montmorot and Bourguignon-les-Morey; Jaccottey 2011).

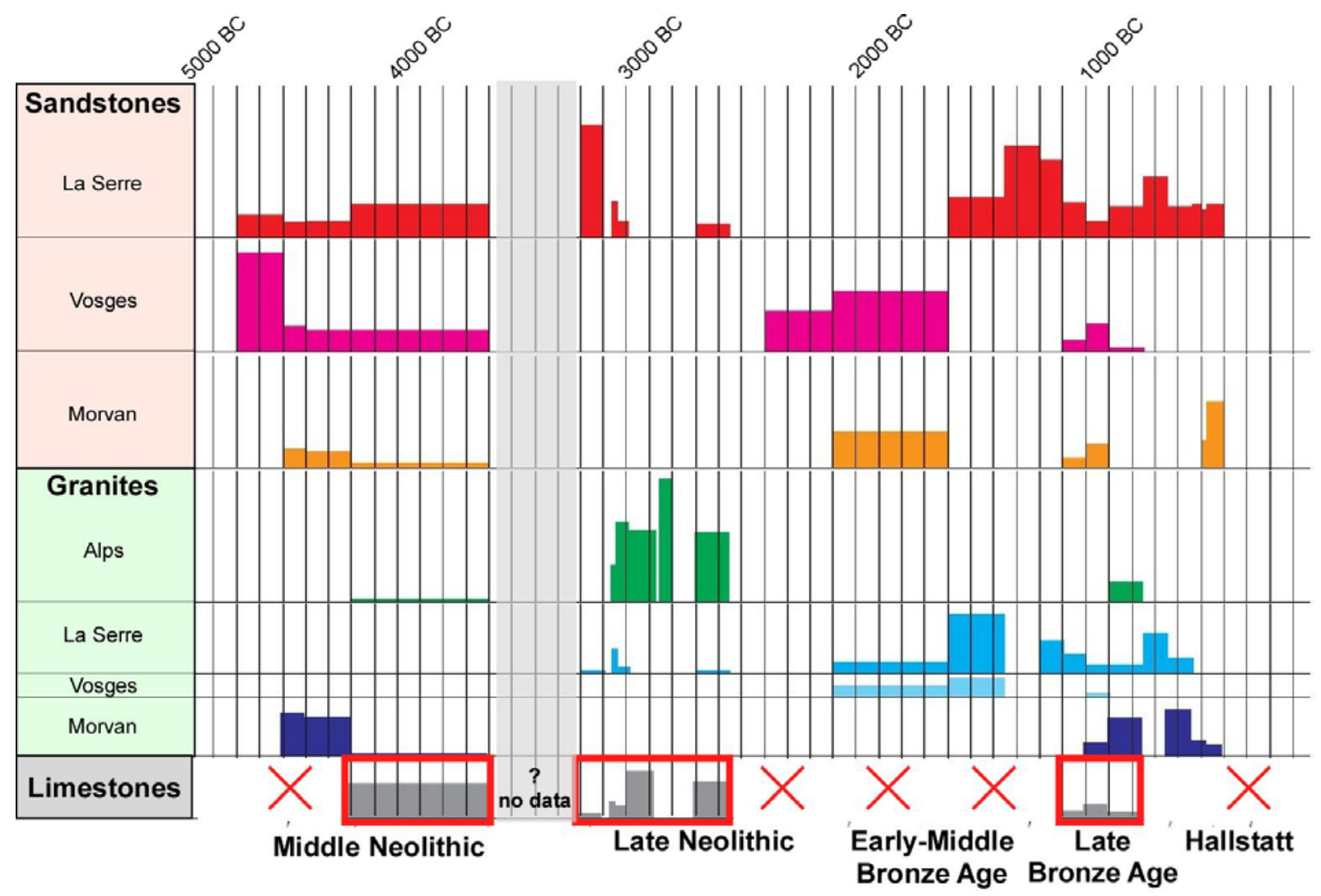

Evidence of limestone quern use

No evidence of limestone quern use

Figure 10. Lithological characterization of saddle querns in Bourgogne-Franche-Comté (France), from Neolithic to Early Iron Age (from Jaccottey \& Milleville 2017).

The use of several types of limestone (recrystallised limestone with angular grains, fine or chalky limestones containing shells) is recorded at certain sites from the Burgundian Middle Neolithic, in the heart of limestone districts. These sites are also characterised by the use of limestone as temper in pottery production. Moreover, limestone millstones are occasionally identified during the Late Neolithic at the settlements of Chalain and Clairvaux. In this period, the increase in the proportion of limestone quern finds can be linked to a rise in population and points to the exploitation of a secondary or backup local raw material that appears to have been quickly rejected again, as the limestone quern finds at these sites are always whole or in large fragments (Milleville 2007: 168). Only in the Late Bronze Age this type of rock is used once again for saddle querns, in the form of limestone breccias and local shell-rich limestones. These limestone querns correspond to cultural markers reflecting particular strategies of supply. A similar alternation between limestone and sandstone for grinding tools is also observed in the sites of the Aisne Valley (Pommepuy 1999; Hamon 2006). Furthermore, a social interpretation is advanced for the sites of the Michelsberg 
Culture in this geographical area, highlighting the role of women in the Neolithic economy (Monchablon, in press). Yet it must be emphasised that the choice of limestones during the Middle Neolithic II is not uniform according to the different cultural groups under study. This rock was chosen for querns in the majority of Michelsberg sites of the Aisne and the Bourguignon Middle Neolithic of the Franche-Comté (Milleville \& Jaccottey 2015) but is totally absent from the assemblages of the Northern Chasséen Culture (Montchablon \& Huyart 2017).

\section{Conclusion}

According to the various examples shown in this article, the selection and the specific use of limestone to produce querns are demonstrated not only in the case of sandy limestones, but also for pure limestones. This is evidence for a deliberate raw material choice and not for mere opportunism. So, it is necessary to try to identify the reasons behind the choices. Yet this type of analysis is only possible in case studies within the framework of specific periods and areas. Nevertheless, as a conclusion, we provide certain guidelines to interpret the potential assemblages made up entirely or partly of limestone querns. In the diagram presented in Figure 11, as an example, we summarize the advantages and disadvantages of two kinds of materials frequently observed in the north of France, according to various parameters. Limestone features are defined according to the various examples described in this article, while volcanic rocks' features are defined according to bibliography (mainly Delgado-Raack et al. 2009 and Gluhak \& Hofmeister 2009; 2011).

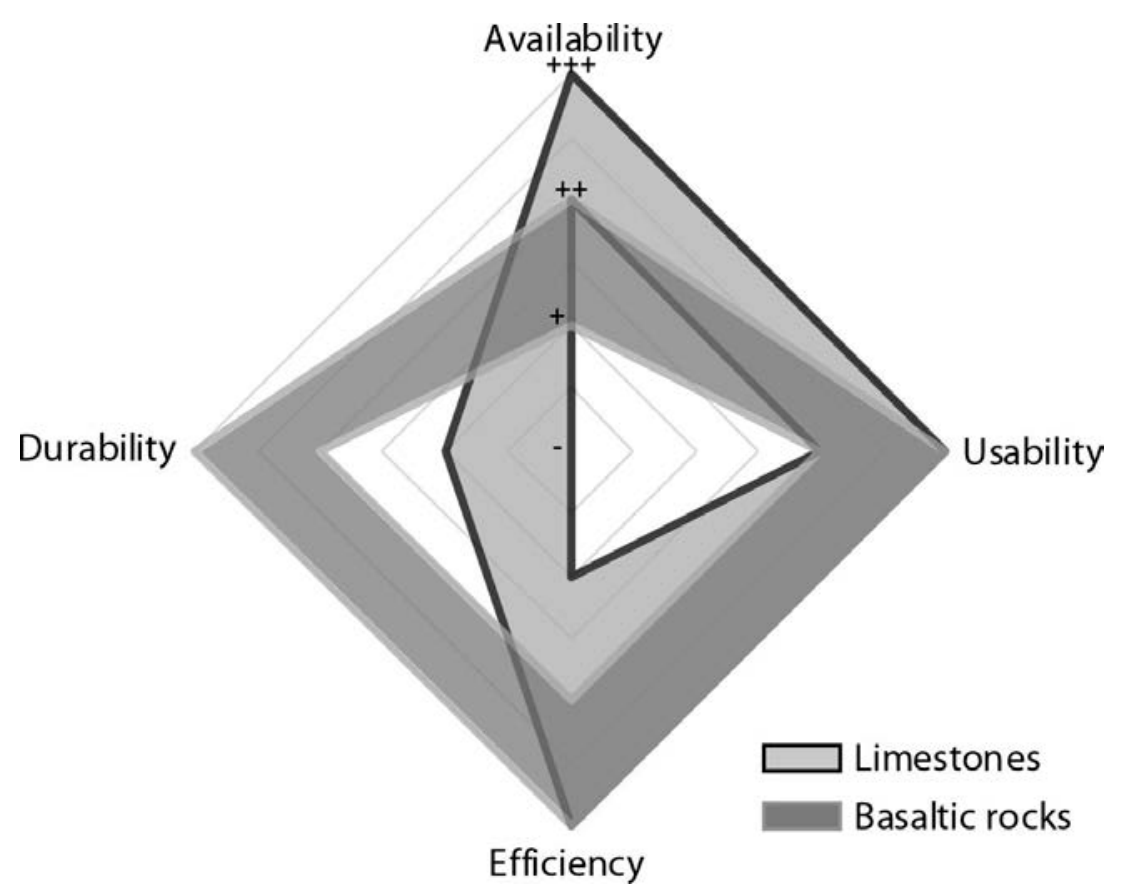

Figure 11. Diagram indicating the advantages (+: very few advantages, ++: clear advantages, and +++: strong clear advantages) and clear disadvantages (-) of limestone millstones compared to volcanic rocks among the Reims quern assemblage (France).

- Availability: Limestones are common in most sedimentary basins. They generally form readily accessible outcrops or deposits, exposed by erosion on the flanks of valleys or plateaus and are quite easy to extract. In these geological contexts, a wide diffusion of the products of these sites seems self-evident due to the large number of outcrops yielding a large available volume of stone. Their abundance and extent of their surface 
facilitates their diffusion regardless of the types of distribution circuits. Limestones are therefore rocks with good accessibility and great potential of supply:

\section{Limestone $=$ Availability from ++ to +++}

- Usability: Limestones often crop out in the form of benches characterised by jointing, bedding and fractures that facilitate their extraction in the form regular stone blocks. Moreover, they are rocks that are relatively easy to cut and shape, at least when compared to crystalline rocks. Although this criterion requires a confirmation by case studies and experimentation due to the heterogeneous nature of limestones, they generally offer an easy extraction and fashioning:

\section{Limestone $=$ Usability from ++ to +++}

- Durability: Limestones are softer than most other millstone materials and at times completely devoid of hard minerals (following the Mohs hardness scale with calcite at 3 as opposed to quartz at 7):

\section{Limestone $=$ Durability from - - to -}

- Efficiency: Although this aspect of millstone research requires experimentation and quantitative data, which is not within the scope of the current study, the abundance and widespread diffusion of limestone querns and millstones supports the hypothesis that they obviously were considered efficient. This assumption leads to the following notion:

Millstone $=$ Efficiency from + to +++

\section{Acknowledgments}

We thank Simon Painsonneau and the company Arkemine for the photo of the millstone roughout excavated in 2013 at Jacob-Bellecombette (Savoie). We also thank all the members of the Groupe Meule for their collaboration as well as the French Ministry of Culture for the grants to fund the different research programmes (DRAC Champagne-Ardenne, DRAC Centre-Val-de-Loire).

\section{References}

Anderson, T. 2016, Turning Stone to Bread. A Diachronic Study of Millstone Making in Southern Spain. Southampton Monographs in Archaeology New Serie, 5, 2 vol. The Highfield Press Southampton, Eastleigh, 636 p.

Anderson, T., Agustoni, C., Duvauchelle, A., Serneels, V., \& Castella, D. 2003, Des artisans à la campagne : carrière de meule, forge et voie gallo-romaine à Châbles, Coll. Archéologie Fribourgeoise 19, Academic Press Fribourg, Fribourg, 391 p. (in French) ("Craftmen in countryside: millstones quarry, forge and gallo-roman road at Châbles")

Audebert, A., \& Le Quellec V. 2014, Le matériel de mouture des habitats du Pôle d'activités du Griffon, à Barenton-Bugny et Laon (Aisne). In: Consommer dans les campagnes de la Gaule romaine, Actes du Xe Congrès de l'association AGER, Villeneuve d'Ascq (Deru, X., \& Gonzalez-Villaescusa, R., Eds.), Revue du Nord, Coll. Art et Archéologie, Hors-série 21: p. 67-84. (in French) ("Grinding tools from the Pôle du Griffon habitats, Barenton-Bugny and Laon (Aisne)") 
Benoît, P., Blanc, A., Gély, J.-P., Guini-Skliar, A., Obert, D., \& Viré, M. 2000, La pierre de Paris, Méthode d'étude de la pierre à bâtir depuis son extraction jusqu'à sa mise en œuvre. In: La pierre dans la ville antique et médiévale. Actes du colloque d'Argentomagus, 1998, Tours (Lorenz, J., Tardy, D., \& Coulon, G. Eds.), Supplément à la Revue archéologique du centre de la France, 18: 121-158. (in French) ("The stone of Paris, Methodology for building stones study, from quarrying to uses"). www.persee.fr/doc/sracf_1159-7151_2000_act_18_1_1095

Boyer, F., \& Fronteau, G. 2011, Les géomatériaux meuliers: de l’identification des sources géologiques à la définition de catégories de gisements. In: Evolution typologique et technique des meules du Néolithique à l'an mille, Actes des IIIème rencontres de l'Archéosite gaulois (Buchsenschutz, O., Jaccottey, L., Jodry, F. \& Blanchard, J.L., Eds.). Aquitania, Supl. 23: 121-135. (in French) ("Millstones geomaterials: from provenancing to the definition of deposit categories")

Brilli, M., Conti, L., Giustini, F., Occhiuzzi, M., Pensabene, P., \& De Nuccio, M. 2011, Determining the provenance of black limestone artifacts using petrography, isotopes and EPR techniques: the case of the monument of Bocco. Journal of Archaeological Science, 38(6): 1377-1384. doi:10.1016/j.jas.2011.02.005

Buchsenschutz, O., Fronteau, G., Jaccottey, L., Jodry, F., \& Saurel, M. 2017, Les meules gauloises d'Acy-Romance (Ardennes), In: Les meules à grain du Néolithique à l'Époque Médiévale: technique, culture, diffusion. Actes du 2e colloque du Groupe Meule, Reims du 15 au 17 mai 2014 (Buchsenschutz O., Lepareux-Couturier S., \& Fronteau G., Eds.), Société Archéologique de l’Est, Revue Archéologique de l’Est , supplément 43, Dijon, p. 117-134. (in French) ("Gallic rotary millstones from AcyRomance, Ardennes")

Choquette, P.W., \& Pray, L.C. 1970, Geological nomenclature and classification of porosity in sedimentary carbonates. American Association of Petroleum Geologists Bulletin, 54(2): 207-250.doi:10.1306/5d25c98b-16c1-11d7-8645000102c1865d

Dalmau, L. 2015, La cathédrale Notre-Dame de Thérouanne: le lapidaire inédit du portail sud. Revue du Nord, 97(5): 253-280. (in French) ("The Cathedral of Notre Dame, Thérouanne: publication of the lapidary of the south portal"). doi:10.3917/rdn.413.0253

Delgado-Raack, S., Gomez-Gras, D., \& Risch, R. 2009, The mechanical properties of macrolithic artifacts: a methodological background for functional analysis. Journal of Archaeological Science, 36(9): 1823-1831. doi:10.1016/j.jas.2009.03.033

Degryse, P., Muchez, P., Lieven, L., Vandeput, L., \& Waelkens, M. 2003, The Building Stones of Roman Sagalassos (SW Turkey): Facies Analysis and Provenance. Facies, 48(1): 9-22. doi:10.1007/BF02667527

Devos, A., Fronteau, G., Lejeune, O., Sosson, C., Chopin, E., \& Barbin, V. 2010, Influence of geomorphological constraints and exploitation techniques on stone quarry spatial organisation. Example of Lutetian underground quarries in Rheims, Laon and Soissons areas. Engineering Geology, 115(3-4): 268-275. doi:10.1016/j.enggeo.2010.05.004

Dix, B. 1982, The manufacture of lime and its uses in the Western roman provinces. The Oxford Journal of Archaeology, 1(3): 331-346. doi:10.1111/j.14680092.1982.tb00318.x 
Donnart, K. 2015, Le macro-outillage dans l'Ouest de la France : pratiques économiques et techniques des premières sociétés agropastorales, $\mathrm{PhD}$ Thesis. University of Rennes1, Rennes (France), 659 p. (in French) ("Macro-tools from the West of France: economical and technical practices of the first agro-pastoral societies")

Dunham, R.J. 1962, Classification of carbonate rocks according to depositional texture. American Association of Petroleum Geologists Memoir, 1: 108-121.

Embry, A.F, \& Klovan J.E. 1971, A late Devonian reef tract on Northeastern Bank Island, Northwest Territories. Canadian Petroleum Geology Bulletin, 19(4): 730-781.

European standard 2003, EN 12670, Natural stone. Terminology. AFNOR, La Plaine SaintDenis, $52 \mathrm{p}$.

European standard 2007, EN 12407, Natural stone test methods. Petrographic examination. AFNOR, La Plaine Saint-Denis, 15 p.

European standard 2008, EN 12440, Natural stone. Denomination criteria. AFNOR, La Plaine Saint-Denis, 106 p.

Ferrini, V., De Vito, C., Mignardi, S., \& Venanzio Fucinese, D. 2012, Archaeological carved slabs of the Langobard art in churches of Peligna Valley and Spoleto (Italy): provenance of the stones. Journal of Archaeological Science, 39(12): 3505-3515. doi:10.1016/j.jas.2012.06.023

Flügel, E. 2010, Microfacies of Carbonate Rocks, Analysis, Interpretation and Application. Springer-Verlag, Berlin, Heidelberg. 984 p. doi:10.1007/978-3-642-03796-2

Folk, R.L. 1959, Practical petrographical classification of limestones. American Association of Petroleum Geologists Bulletin, 43(1): 1-38. doi:10.1306/0bda5c36-16bd-11d78645000102c1865d

Fronteau, G., Barbin, V., \& Pascal, A. 1999, Impact du faciès sédimento-diagénétique sur l'altération en œuvre d'un géomatériau calcaire. C. R. Acad. Sci. Paris, Series IIA Earth and Planetary Science, 328(10): 671-677. (in French) ("Impact of sedimentarydiagenetic facies on weathering of carbonate building stone"). doi:10.1016/S12518050(99)80176-1

Fronteau, G., Moreau, C., Thomachot-Schneider, C., \& Barbin, V. 2010, Variability of some Lutetian building stones from the Paris Basin, from characterisation to conservation. Engineering Geology, 115(3-4): 158-166. doi:10.1016/j.enggeo.2009.08.001

Fronteau, G., \& Boyer, F. 2011, Roches meulières: de la classification pétrographique à la classification texturale d'un potentiel mécanique. In: Evolution typologique et technique des meules du Néolithique à l'an mille, Actes des IIIème rencontres de l'Archéosite gaulois (Buchsenschutz, O., Jaccottey, L., Jodry, F. \& Blanchard, J.L., Eds.). Aquitania, Supl. 23: 111-120. (in French) ("Millstones rocks: from petrographical classification to the definition of a mechanical potential")

Fronteau, G., Boyer, F., Frouin, M., Jaccottey, L., Lepareux-Couturier, S., Milleville, A. \& Picavet, P. 2017, Les principales pierres meulières utilisées en Champagne-Ardenne: gisements, matériaux, utilisations, In: Les meules à grain du Néolithique à l'Époque Médiévale: technique, culture, diffusion. Actes du $2 e$ colloque du Groupe Meule, Reims du 15 au 17 mai 2014 (Buchsenschutz, O., Lepareux-Couturier, S., \& Fronteau, G., Eds.), Société Archéologique de l'Est, Revue Archéologique de l’Est, supplément 43, Dijon: 35-52. (in French) ("Main millstones rocks from Champange-Ardenne area: deposits, material, uses") 
Gluhak, T.M., \& Hofmeister, W. 2009, Roman lava quarries in the Eifel region (Germany): geochemical data for millstone provenance studies. Journal of Archaeological Science, 36(8): 1774-1782. doi:10.1016/j.jas.2009.04.007

Gluhak, T.M., \& Hofmeister, W. 2011, Geochemical provenance analyses of Roman lava millstones north of the Alps: a study of their distribution and implications for the beginning of Roman lava quarrying in the Eifel region (Germany). Journal of Archaeological Science, 38(7): 1603-1620. doi:10.1016/j.jas.2011.02.025

Grabau, A.W., 1904, On the classification of sedimentary rocks. American Geologist, 33: 228-247.

Hamon, C., Ambert, P., Laroche, M., Guédon, J.-L., Rovira, S., \& Bouquet, L. 2009, Les outils à cupules, marqueurs de la métallurgie du district de Cabrières-Péret (Hérault) au Chalcolithique. Gallia Préhistoire, 51: 179-212. (in French) ("Cupule-tools, markers of metallurgy if the Cabrières-Péret district area (Hérault)"). doi:10.3406/galip.2009.2478

Hamon, C. \& Fronteau G. 2018, Linear Pottery Culture sandstone supply strategies in northwestern Europe: The example of macrolithic tool production in the Aisne Valley, France (late 6th millennium BCEE). Journal of Archaeological Science Reports, 19: 301-311. doi:10.1016/j.jasrep.2018.02.049

Hamon, C. 2006, Broyage et abrasion au Néolithique ancien. Caractérisation technique et fonctionnelle des outillages en grès du Bassin parisien. BAR International Reports S1551, Archaeopress, Oxford, 342 p. (in French) ("Grinding and abrading in the early Neolithic. Technological and functional analysis of sandstone from the Paris Basin").

Harrell, J.A., \& Storemyr, P. 2009, Ancient egyptian quarries - an illustrated overview. In: QuarryScapes: ancient stone quarry landscapes in the Eastern Mediterranean (AbuJaber, N., Bloxam, E.G., Degryse, P. \& Heldal, T., Eds.), Geological Survey of Norway. Special publication, 12, p. 7-50. http://www.ngu.no/upload/Publikasjoner/Special publication/SP12_s7-50.pdf

Jaccottey, L. 2011, Gestion des matières premières et implantation humaine au Néolithique dans le Nord-Jura. Master of Archaeology thesis. University de Franche-Comté, Besançon, 306 p. (in French) ("Management of raw materials and human settlements during Neolithic in North-Jura")

Jaccottey, L., \& Milleville, A. 2017, 7000 ans d'exploitation meulière dans le massif de la Serre. In: Les meules à grain du Néolithique à l'Époque Médiévale: technique, culture, diffusion. Actes du 2e colloque du Groupe Meule, Reims du 15 au 17 mai 2014, (Buchsenschutz, O., Lepareux-Couturier, S., \& Fronteau, G., Eds.), Société

Archéologique de l'Est, Revue Archéologique de l'Est, Dijon, supplément 43: 191-211. (in French) ("7000 years of millstone quarrying activity in the Serre Massif")

Jodry, F., Rollet, P., Picavet, P., Moiret, F., Fronteau, G., \& Balmelle, A. 2017, Meules antiques de Reims (Marne, France). In: Les meules à grain du Néolithique à l'Époque Médiévale: technique, culture, diffusion. Actes du 2e colloque du Groupe Meule, Reims du 15 au 17 mai 2014, (Buchsenschutz, O., Lepareux-Couturier, S., \& Fronteau, G., Eds.), Société Archéologique de l’Est, Revue Archéologique de l'Est, Dijon, supplément 43: p. 135-145 (in French) ("Rotary millstones from Antiquity at Reims (Marne, France)") 
Karkanas, P. 2007, Identification of lime plaster in prehistory using petrographic methods: a review and reconsideration of the data on the basis of experimental and case studies. Geoarchaeology, 22(7): 775-796. doi:10.1002/gea.20186

Larocca, F. 2016, Ground stone percussion tools from Maltese Islands. Journal of Lithic Studies, 3(3): 291-300. doi.org/10.2218/jls.v3i3.1674

Lepareux-Couturier, S. 2014, Complex dressing patterns on grinding surfaces of rotary querns and millstones from Antiquity in the Paris Basin, France: state of research and perspectives, In: Seen through a millstone, Proceedings of the Bergen Conference (Selsing, L., Ed.), AmS Skritter, 24, Stavanger: p. 225-234.

Martínez-Torres, L.M. 2009, The typology of ancient quarries within the Paleocene limestone of Álava in northern Spain. Geoarchaeology, 24: 42-58. doi:10.1002/gea.20252

Milleville, A. 2007, De la pierre à la meule durant le Néolithique, circulation et gestion des matières premières entre Rhin et Rhône. PhD Thesis. University of Franche-Comté, 418 p. (in French) ("From stone to millstones during Neolithic, diffusion and management of raw materials between Rhine and Rhône")

Milleville, A., \& Jaccottey, L. 2015, Le macro-outillage du Néolithique moyen: couples meule-molette, polissoirs, percuteurs et blocs enclumes. In: Clairvaux et le Néolithique Moyen Bourguignon (Pétrequin, P., Pétrequin A.-M., Eds), Presses Universitaires de Franche-Comté, Besançon, 1339(2), p. 1029-1070. (in French) ("Macro-tools from Middle Neolithic: rotary querns, polishers, percussors and anvil-blocks")

Montchablon, C., Huyart, V. 2017. L'assemblage macrolithique de Passel. In: Passel, Le Vivier (Oise). Une enceinte du Néolithique moyen II (Cayol N., Ed.), SRA Hauts-deFrance, INRAP, Amiens. vol. 2, p. 270-296 (Macrolithique tools, Passel, Le Vivier (Oise), an enclosure from the Middle Neolithic II”)

Monchablon, C. In press, Les molettes des enceintes du Néolithique moyen II du nord de la France : entre outils fonctionnels et objets symboliques, In: Actes du 32e colloque interrégional sur le Néolithique (Le Mans, 24 et 25 novembre 2017 (Fronmont, N., \& Marchand, G. Edd.), Presse Universitaire de Rennes. Rennes. (in French) ("Querns from Middle Néolithic NMII enclosures of North (France)")

Michelot, P. 1863, Expériences sur la résistance des matériaux à l'écrasement. Annales des ponts et chaussées. Mémoires et documents relatifs à l'art des constructions et au service de l'ingénieur: 185-208. (in French) ("Experiments on the strength of geomaterials")

Naze, Y., Fronteau, G., \& Robert, B. 2011, L'atelier de meules rotatives en calcaire à cérithes de Vendresse-Beaulne (Aisne). Note à propos des outils de mouture en calcaire Lutétien ", In: Evolution typologique et technique des meules du Néolithique à l'an mille, Actes des IIIème rencontres de l'Archéosite gaulois (Buchsenschutz, O., Jaccottey, L., Jodry, F. \& Blanchard, J.L., Eds.). Aquitania, Supl. 23: 269-283. (in French) ("The rotary millstones quarry in cerithium limestones from Vendresse-Beaulne (Aisne), note about the milling stones in lutetian limestones")

Noël, P. 2012, Technologie de la pierre de taille. Dictionnaire des termes couramment employés dans l'extraction, l'emploi et la conservation de la pierre de taille. $2^{\text {nd }}$ Edition (1st Ed, 1968). SEBTP, Paris, 369 p. (in French) ("Technology of dimension stones. Dictionary of terms commonly used in the extraction, use and conservation of dimension stone") 
Peacock, D.P.S. 1987, Iron Age and Roman quern production at Lodsworth, West Sussex, The Antiquaries Journal, 67(1): 61-85. doi:10.1017/S0003581500026287

Picavet, P., Fronteau, G., \& Boyer, F. 2011, Les meules romaines de sept chefs-lieux de cité de Gaule Belgique occidentale, étude du matériel et synthèse bibliographique. Revue du Nord, 93(5): 167-226. (in French) ("The Roman Millstones of Seven Capitals of Western Belgian Gaul, a Study of the Material and a Bibliographical Synthesis "). doi:10.3917/rdn.393.0167

Picavet, P., Reniere, S., Cnudde, V., De Clerq, W., Dreesen, R., Fronteau, G., Goemaere E., \& Hartoch, E. 2018, The Macquenoise sandstone: a suitable Lochkovian (Devonian) raw material for ancient millstones: quarries, properties, manufacture and distribution (Belgium-France). Geologica Belgica, 21(1-2): 27-40. doi:10.20341/gb.2018.002

Pommepuy C. 1999, Le matériel de mouture de la vallée de l’Aisne de l’Âge du Bronze à La Tène finale : formes et matériaux. Revue Archéologique de Picardie, 1999(3-4): 115-141. (in French) ("Milling tools in Aisne Valley from the Bronze Age to La Tène final: morphologies and materials"). doi:10.3406/pica.1999.2217

Prøsch-Danielsen, L. \& Heldal, T. 2014, A local millstone quarry at Nord-Talgje in Southwest Norway: mapping, interpretation and age estimate. In: Seen through a millstone, Proceedings of the Bergen Conference (Selsing, L., Ed.), AmS Skritter, 24, Stavanger: p. 196-208.

Reedy Chandra, L. 2008, Thin-section Petrography of Stone and Ceramic Cultural Materials. Archetype Publications. London, 264 p.

Reniere, S., De Clercq, W., Dreesen, R., Goemaere, E., Fronteau, G., Gluhak, T., Hartoch, E., \& Picavet, P. 2016, Querns and mills during Roman times at the northern frontier of the Roman Empire (Belgium, Northern France, Southern Netherlands, Western Germany): Unraveling geological and geographical provenances, a multidisciplinary research project. Journal of Lithic Studies, 3(3): 403-428. doi:10.2218/jls.v3i3.1640

Robert, B., \& Landreat, J.-L. 2005, Les meules rotatives en calcaire à glauconie grossière et l'atelier de Vauxrezis (Aisne). Un état de la question. In: Hommage à Claudine Pommepuy (Auxiette, G., \& Malrain, F., Eds.), Revue Archéologique de Picardie, NS 22: 105-114. (in French) ("Rotary millstones in coarse glauconitic limestones and Vauxrezis workshop (Aisne)"). doi:10.3406/pica.2005.2723

Scholle, P. \& Ulme-Scholle, D.S. 2003, A Color Guide to the Petrography of Carbonate Rocks: Grains, textures, porosity, diagenesis. American Association of Petroleum Geologists Vol. 77, 474 p. doi:10.1306/M77973

Schoumacker, A. 1993, Apports de la technologie et de la pétrographie pour la caractérisation des meules. In: Traces et fonction: les gestes retrouvés. Actes du colloque international de Liège. 8-9-10 décembre 1990 (Anderson, P.C., Beyries, S., Otte, M., Plisson, H. Eds.), ERAUL, 50: p. 165-176. (in French) ("Benefits of technological approach and petrography to millstones characterization")

Spivak, P., \& Nadel, D. 2016, The use of stone at Ohalo II, a 23,000 year old site in the Jordan Valley, Israel. Journal of Lithic Studies, 3(3): 523-552. doi:10.2218/jls.v3i3.1646

Tucker, M.E., \& Wright, V.P. 1990, Carbonate sedimentology, Blackwell Scientific Publications, Oxford, 425 p. doi:10.1002/9781444314175 
Viscusi-Simonin, V., \& Jaccottey, L. 2013, Faire parler les pierres: approche de l'évolution de la villa de Brans (Jura) par le biais de ses approvisionnements en matériaux de construction. Revue Archéologique de l'Est, 62: 231-251. (in French) ("Make the stones speak: approach of the modification in the Brans villa (Jura) through the building materials supplies"). https://journals.openedition.org/rae/7727

Wright, V.P. 1992, A revised classification of limestone. Sedimentary Geology, 76(3-4): 177185. doi:10.1016/0037-0738(92)90082-3 